\title{
Pengaruh Kompetensi, Insentif dan Motivasi terhadap Kinerja Pegawai pada Badan Narkotika Nasional Provinsi Kalimantan Tengah
}

\author{
Jalmo Hadi Prayitno ${ }^{1,2,{ }^{*}}$, Asriansyah S. Mawung ${ }^{3,}$, Achmad Syamsudin $^{3}$ \\ ${ }^{1}$ Alumni Program Studi Magister Manajemen Universitas Palangka Raya \\ 2 Badan Narkotika Nasional Provinsi Kalimantan Tengah \\ ${ }^{3}$ Dosen Program Studi Magister Manajemen Universitas Palangka Raya \\ * Korespondensi: Jalmo Hadi Prayitno (Email: ertiga1973@gmail.com )
}

\begin{abstract}
During the last 2 years (in 2018 and 2019) drug cases in Central Kalimantan Province had increased. As agency in charge of the task, the Provincial National Narcotics Agency (BNNP) of Central Kalimantan, therefore, requires more staffs with specific skills and good performance. The purpose of this study was to determine the effect of competence, incentives and motivation on staffs performance in BNN of Central Kalimantan Province. Primary data were collected from interviews. Secondary data, i.e. the number of BNNP staffs and the number of cases revealed and investigated obtained through media liaison or such as books, notes, evidence that already exists, or archives both published and not published. The respondents were all 37 of Central Kalimantan BNNP staffs. Data were analyzed through validity test, reliability test, hypothesis test, descriptive statistical analysis, inferential analysis, and model evaluation. The results showed that competence and motivation have a significant effect on performance, while the provision of incentives do not have a significant effect on performance.
\end{abstract}

\section{Keywords}

Competence, incentives, motivation, performance, BNNP Central Kalimantan

\section{PENDAHULUAN}

Badan Narkotika Nasional (BNN) merupakan Lembaga Pemerintah Non Kementerian Indonesia yang melaksanakan tugas pemerintahan di bidang pencegahan, pemberantasan penyalahgunaan dan peredaran gelap psikotropika, prekursor, dan bahan adiktif lainnya kecuali bahan adiktif untuk tembakau dan alcohol. Badan Narkotika Nasional Provinsi (BNNP) adalah instansi vertikal BNN yang melaksanakan tugas, fungsi, dan wewenang BNN dalam wilayah Provinsi.

BNNP mempunyai tugas melaksanakan tugas BNN dalam wilayah Provinsi. Tugas BNNP diantaranya adalah: 1) menyusun dan melaksanakan kebijakan nasional mengenai pencegahan dan pemberantasan penyalahgunaan dan peredaran gelap narkotika dan prekursor narkotika; 2) mencegah dan memberantas penyalahgunaan dan peredaran gelap narkotika dan prekursor narkotika; 3) berkoordinasi dengan Kepala Kepolisian Negara Republik Indonesia dalam pencegahan dan pemberantasan penyalahgunaan dan peredaran gelap narkotika danprekursor narkotika; 4) meningkatkan kemampuan lembaga rehabilitasi medis dan rehabilitasi sosial pecandu narkotika, baik yang diselenggarakan oleh pemerintah maupun masyarakat; 5) memberdayakan masyarakat dalam pencegahan penyalahgunaan dan peredaran gelap narkotika dan prekursor narkotika; 6) memantau, mengarahkan, dan meningkatkan kegiatan masyarakat dalam pencegahan penyalahgunaan dan peredaran gelap narkotika dan prekursor narkotika; 7) melakukan kerja sama bilateral dan multilateral, baik regional maupun internasional, guna pencegahan, pemberantasan, penyalahgunaan dan peredaran gelap narkotika dan prekursor narkotika; 8) mengembangkan laboratorium narkotika dan prekursor narkotika; 9) melaksanakan administrasi penyelidikan dan penyidikan terhadap perkara penyalahgunaan dan peredaran gelap narkotika dan prekursor narkotika; dan 10) membuat laporan tahunan mengenai pelaksanaan tugasdan wewenang.

BNNP berwenang melakukan penyelidikan serta penyidikan terhadap penyalahgunaan dan peredaran 
gelap narkotika dan bahan prekursor untuk melaksanakan tugas dalam Pemberantasan Penyalahgunaan Serta Peredaran Gelap Narkotika (P4GN) dan prekursor narkotika. Adapun fungsi khusus dari BNNP diantaranya adalah: a) Pelaksanaan kebijakan teknis P4GN di bidang pencegahan, pemberdayaan masyarakat, pemberantasan, dan rehabilitasi; b) Pelaksanaan penyiapan bantuan hukum dan kerja sama; c) Pelaksanaan pembinaan teknis di bidang P4GN kepada (BNN) Kabupaten/Kota; d) Penyusunan rencana program dan anggaran BNNP; e) Evaluasi dan penyusunan laporan BNNP; dan f) Pelayanan administrasi BNNP.

BNNP Kalimantan Tengah berdiri pada tanggal 1 Oktober 2011 berdasarkan UU Nomor: 35 tahun 2009 tentang Badan Narkotika Nasional dan Paraturan Kepala BNN Nomor: PER/4/V/2010 tanggal 12 Mei 2010 tentang organisasi dan tata kerja. Dalam pelaksanaan tugas dan fungsinya, BNNP Kalimantan Tengan telah mampu mengungkap dan menyidik berbagai kasus narkoba.

Beberapa penyidikan dan pengungkapan kasus yang pernah dilakukan, diantaranya yaitu pada tahun 2018 sebanyak 18 kasus dan pada tahun 2019 sebanyak 24 kasus. Selama 2 tahun terkahir ini kasus narkoba di Provinsi Kaimantan Tengah mengalami peningkatan. Dengan meningkatnya kasus yang dihadapi pegawai di lapangan, tentu akan memerlukan sumber daya manusia (SDM) yang lebih banyak dan membutuhkan kinerja yang lebih baik. BNNP Kalimantan Tengah dalam melaksanakan tugas pokok dan fungsinya membutuhkan pegawai yang memiliki kinerja yang baik. Sekarang ini modus peredaran narkoba sudah dilakukan dengan berbagai cara, baik dalam lintas internasional maupun regional. Sehingga menjadi tantagan yang berat bagi pegawai BNNP Kalimantan Tengah.

Terdapat banyak faktor yang mempengaruhi kinerja pegawai. Menurut Armstrong (2009), faktor-faktor mempengaruhi kinerja pegawai tersebut diantaranya, yaitu: a) faktor individu (personal factors); b) faktor kepemimpinan (leadership factors); c) faktor kelompok atau rekan kerja (team factors); d) faktor sistem (system factors); e) faktor situasi (contextual/situational factors)

Menurut Spencer dan Spencer dalam Moeheriono (2010), kompetensi adalah karakteristik yang berkaitan terhadap efektivitas kinerja dalam melaksanakan pekerjaannya atau yang memiliki hubungan sebab akibat dengan kriteria yang dijadikan sebagai acuan, efektif atau berkinerja prima atau superior di tempat kerja atau pada situasi tertentu.

Costa et al. (2001) menyatakan bahwa kompetensi adalah kemampuan dalam melaksanakan tugas, kemampuan dalam mengintegrasikan pengetahuan, keterampilan, sikap serta nilai-nilai pribadi, kemampuan guna membangun pengetahuan maupun keterampilan berdasarkan pengalaman dan pembelajaran yang dilakukan. Selanjutnya menurut Ruky (2006), kompetensi adalah perpaduan dari keterampilan (skill), pengetahuan (knowledge) dan perilaku yang dapat dilihat dan diterapkan secara kritis untuk mensukseskan sebuah organisasi dan prestasi kerja serta kontribusi pribadi karyawan terhadap organisasinya. Hasil penelitian Marpaung et al. (2015), Sari (2018), dan Fahrul (2016) menunjukkan bahwa kompetensi berpengaruh terhadap kinerja pegawai.

BNNP Kalimantan Tengah dalam melakukan pengungkapan dan penyidikan kasus narkoba selalu memberikan insentif kepada para pegawa yang bertugas dan telah dituangkan dalam anggaran. Pemberian insentif tersebut diharapkan dapat mendorong kinerja pegawai lebih baik dalam pengungkapan dan penyidikan kasus narkoba.

Dessler (2009) mengungkapkan bahwa insentif merupakan pendapatan diluar gaji pokok yang diberikan kepada pegawai/karyawan yang berhasil mencapai standar kinerja yang ditentukan. Menurut Hasibuan (2005), insentif ialah tambahan balas jasa diberikan kepada karyawan tertentu yang mempunyai prestasi diatas standar. Insentif merupakan alat yang dipergunakan sebagai pendukung prinsip adil dalam pemberian kompensasi. Handoko (2013) menyatakan bahwa insentif ialah perangsang yang ditawarkan kepada karyawan untuk melaksanakan kerja sesuai dan atau lebih tinggi dari standar-standar yang sudah ditetapkan. Aisha dan Hardjomidjojo (2014) menunjukkan bahwa kondisi kerja, insentif dan motivasi memiliki pengaruh yang signifikan secara statistik terhadap kinerja karyawan.

Motivasi adalah kemauan melakukan pekerjaan dan menentukan kemampuan dalam bertindak untuk memuaskan kebutuhan individu. Kebutuhan (need) yaitu suatu kekurangan baik fisik atau psikologis yang membuat menjadi terlihat menarik (Robbins, 2002) Motivasi merupakan semua proses pemberian dorongan kepada para pegawai supaya mereka dapat bekerja sehingga tujuan organisasi dapat tercapai secara efektif dan efisien (Wursanto, 2003) Menurut Robbins (2002), motivasi yaitu adanya keinginan untuk berusaha sekuat tenaga demi mencapai tujuan organisasi yang telah ditentukan oleh kemampuan usaha untuk memenuhi suatu kebutuhan individu. Motivasi sebagai kebutuhan yang mendukung perbuatan untuk suatu tujuan tertentu. Jadi motivasi kerja adalah sesuatu yang menimbulkan semangat atau dorongan untuk bekerja (Anoraga, 2019). Aisha dan Hardjomidjojo (2014) juga menemukan bahwa motivasi berpengaruh signifikan terhadap kinerja pegawai.

Beberapa penelitian telah dilakukan sebelumnya terkait pengaruh kompetensi, insentif dan motivasi terhadap kinerja. Penelitian yang dilakukan Aisha dan Hardjomidjojo (2014) dengan menggunakan Partial Least Square (PLS) menunjukkan bahwa kondisi kerja, insentif dan motivasi memiliki pengaruh yang signifikan secara statistik terhadap kinerja karyawan. Marpaung et al. (2015) menyatakan bahwa kompetensi individu, insentif dan motivasi berpengaruh secara parsial dan simultan terhadap kinerja pegawai Perum Bulog di Kampar. 
Hasil penelitian yang dilakukan Bahtiar (2016) menunjukkan bahwa motivasi, insentif dan kompetensi berpengaruh positif terhadap kinerja karyawan. Fahrul (2016) menemukan bahwa insentif dan kompetensi berpengaruh positif dan signifikan terhadap kinerja karyawan. Selain itu penelitian Marcelia (2018) menunjukkan bahwa kompetensi dan insentif berpengaruh terhadap kinerja. Sejalan dengan penelitian sebelumnya, Sari (2019) mengungkapkan bahwa terdapat pengaruh positif dan signifikan antara kompetensi, motivasi kerja guru, dan insentif terhadap kinerja guru secara bersama-sama.

Akmal et al. (2018) melakukan penelitian tentang kinerja dengan analisis regresi berganda. Hasil penelitian menunjukkan bahwa variabel X1 (insentif) tidak berpengaruh positif dan signifikan terhadap variabel kinerja karyawan dan variabel X2 (motivasi) berpengaruh positif dan signifikan terhadap variabel $\mathrm{Y}$ (kinerja karyawan).

Berdasarkan permasalahan yang ditemui BNN Provinsi Kalimantan Tengah di lapangan dan beberapa penelitian sebelumnya yang msih terdapat perbedaan, penulis tertarik untuk melakukan penelitian tentang pengaruh kompetensi, insentif dan motivasi terhadap kinerja pegawai pada BNN Provinsi Kalimantan Tengah. Tujuan dari penelitian ini adalah untuk mengetahui pengaruh kompetensi, insentif dan motivasi terhadap kinerja pegawai pada BNN Provinsi Kalimantan Tengah.

\section{METODOLOGI}

Penelitian yang dilakukan bersifat ex post facto dengan pendekatan kuantitatif, yaitu semua informasi diwujudkan dalam bentuk angka, penampilan hasilnya dan analisisnya berdasarkan analisis statistik. Penelitian ini bertujuan menggambarkan keadaan atau fenomena yang terjadi dilapangan. Penelitian ini dimaksudkan untuk menguji hipotesis yang telah dilakukan dengan cara mencari besarnya variabel bebas terhadap variabel terikat.

Teknik pengambilan sampel yang digunakan dalam penelitian ini adalah sampling jenuh, yaitu teknik pengambilan sampel apabila semua populasi dipakai sebagai sampel dan dikenal juga dengan istilah sensus (Sugiyono, 2012). Karena jumlah populasinya sedikit, yaitu sebanyak 37 orang, maka diambil semua sebagai sampel. Jadi responden penelitian ini adalah seluruh pegawai BNNP Kalimantan Tengah. Responden terdiri dari Polri sebanyak 10 orang, pegawai negeri sipil (PNS) sebanyak 23 orang, dan tenaga kerja kontrak (TKK) sebanyak 4 orang. Variabel penelitian ini terdiri dari variabel bebas, yaitu Kompetensi (X1), Insentif (X2), dan Motivasi(X3) Sedangkan variabel terikat adalah Kinerja Pegawai $(Y)$

Jenis data yang digunakan dalam penelitian ini adalah data primer dan data sekunder. Data primer merupakan sumber data penelitian yang didapat secara langsung dari sumber aslinya yang diperoleh melalui wawancara, pengisian kuesioner. Data primer dalam penelitian ini berupa kuesioner atau daftar pertanyaan secara tertulis berkaitan dengan penelitian yang disebarkan kepada seluruh pegawai BNNP Kalimantan Tengah sebagai responden. Data sekunder, yaitu data penelitian yang didapat dari media penghubung atau seperti buku, catatan, bukti yang telah ada, atau arsip baik yang dipublikasikan maupun yang tidak dipublikasikan secara umum. Dalam sekunder dalam penelitian ini antara lain berupa dokumen jumlah pegawai BNNP Kaliamantan Tengah, dan jumlah kasus yang diungkapakan dan penyelididkan.

Data penelitian dikumpulkan dengan beberapa cara diantaranya adalah: dengan a) angket/kuesioner. angket diisi dengan memberikan tanda ceklist pada jawaban yang dipilih; b) wawancara wawancara yaitu mengadakan tanya jawab secara lisan dengan sumber data yang diperlukan; c) dokumentansi. dokumentasi yaitu mempelajari dokumen-dokumen dari hasil laporan organisasi yang dapat dipertanggung jawabkan keabsahan atau kebenarannya

Skala pengukuran yang digunakan pada penelitian ini adalah skala Likert. Skala Likert digunakan untuk mengukur sikap, pendapat, dan persepsi seseorang atau sekelompok orang tentang fenomena sosial. Pada skala Likert responden diminta untuk membubuhkan tanda checklist (Ö) pada salah satu dari lima kemungkinan jawaban yang tersedia, dengan lima penilaian sebagaimana pada Tabel 1.

Tabel 1. Skala likert

\begin{tabular}{lc}
\hline \multicolumn{1}{c}{ Pernyataan Responden } & Skor \\
\hline Sangat Setuju (SS) & 5 \\
Setuju (S) & 4 \\
Ragu-Ragu (R) & 3 \\
Tidak Setuju (TS) & 2 \\
Sangat Tidak Setuju (STS) & 1 \\
\hline
\end{tabular}

Sumber: Sugiyono (2012)

Pada penelitian ini data dianalisis dengan uji validitas, uji reliabilitas, uji hipotesis, analisis statistik deskriptif, analisis inferensial, dan evaliasi model. Uji validitas dilakukan menggunakan convergent validity. Uji validitas convergent indikator refleksi dapat dilihat dari nilai loading factor untuk tiap indikator konstruk. Rule of thumb yang biasa digunakan untuk menilai validitas convergent loading factor harus lebih dari 0,7 untuk penelitian yang bersifat confirmatory dan nilai loading factor 0,6-0,7 untuk penelitian yang bersifat exploratory serta nilai Average Variance Extracted (AVE) harus lebih besar dari 0,5. Namun demikian untuk penelitian tahap awal dari pengembangan skala pengukuran, nilai loading factor 0,5-0,6 masih dianggap cukup (Ghozali, 2012).

Uji reliabilitas konstruk dilakukan dengan dua cara, yaitu Cronbach's Alpha dan Composite Realiability. Nilai 
Composite Realiability harus lebih dari 0,7 untuk penelitian yang bersifat comfirmatory dan nilai 0,6-0,7 untuk penelitian yang bersifat exploratory. Analisis statistik deskriptif digunakan untuk memberikan gambaran atau deskripsi empiris atas data yang dikumpulkan dalam penelitian. Dalam penelitian analisis deskritif menggambarkan persepsi responden atas masing-masing indikator variabel kompetensi, koordinasi dan kinerja.

Pengujian hipotesis penelitian digunakan dengan pendekatan Structural Equation Model (SEM) dengan menggunakan software Partial Least Square (PLS) PLS adalah model berbasis komponen. Menurut Ghozali (2012) PLS adalah pendekatan alternatif yang bergeser dari pendekatan SEM berbasis kovarian menjadi berbasis varian. SEM yang berbasis kovarian umumnya menguji kausalitas/teori, sedangkan PLS lebih bersifat perfective model. PLS merupakan metode analisis yang powerfull (Word dalam Ghozali, 2012). Analaisis ini digunakan untuk menguji pengaruh variabel kompetensi, koordinasi dan Kinerja. Metode analisis data yang digunakan adalah Structural Equation Modeling (SEM) dengan pendekatan Partial Least Sguare (PLS). Untuk melakukan analisis menggunakan Structural Equation Modeling (SEM) dengan pendekatan Partial Least Sguare (PLS) menggunakan langkah-langkah berukut, diantaranya yaitu konseptual model, menentukan metode analisis algorithm, menentukan metode resampling dan menggambar diagram jalur.

Untuk menganalisis hubungan antar variabel laten digunakan evaluasi model struktural atau inner model. Inner model dievaluasi dengan melihat besarnya presentase variance yang dijelaskan yaitu dengan melihat nilai $R^{2}$ untuk variabel laten dependen dengan menggunakan ukuran Stone-Geisser Q Sguare test dan juga melihat besarnya koefisien jalur strukturalnya. Stabilitas dari estimasi ini dievaluasi dengan menggunakan uji t-statistik yang didapat lewat prosedur bootstrapping (Solimun, 2010).

Untuk menilai validitas dan reliabilitas model dilakukan dengan cara evaluasi model pengukuran atau outer model dilakukan. Outer model dengan indicator refleksif dievaluasi melalui viliditas convergent dan discriminant dari indikator pembentuk konstruk laten dan composite reliability untuk blok indikatornya. Sedangkan outer model dengan indikator formatif dievaluasi dengan substantive content-nya yaitu dengan membandingkan besarnya relative weight dan melihat signifikansi dari indikator konstruk tersebut (Chin dalam Ghozali dan Latan, 2012). Teknik analisis outher model dan inner model dijelaskan sebagai berikut:

\section{Evaluasi Model Pengukuran (Outher Model)}

Model ini digunakan untuk mengetahui validitas dan realibilitas yang menghubungkan indikator dengan variabel latennya. Karena semua variabel dalam penelitian ini indikatornya refleksif, maka diperlukan kalibrasi ulang untuk mengetahui validitas dan realibilitas instrument. Cara pengukurannya yaitu:

a. Convergent Validity

Convergent Validity mengukur besarnya korelasi antara konstruk dengan variabel laten. Suatu indikator dikatakan mempunyai realibilitas yang baik jika nilai loading factor lebih besar dari 0,7 sedangkan loading factor 0,5 sampai dengan 0,6 masih dianggap cukup bila digunakan untuk penelitian tahap awal dari pengembangan skala pengukuran.

b. Discriminant validity

Nilai ini merupakan nilai cross loading faktor yang berguna untuk mengetahui apakah konstruk memiliki diskriminan yang memadai yaitu dengan cara membandingkan nilai loading pada konstruk yang dituju harus lebih besar dibandingkan dengan nilai loading dengan konstruk yang lain.

c. Composite Reliability

Composite Reliability digunakan untuk menguji reliabilitas suatu konstruk. Rule of thumb yang biasanya digunakan untuk menilai reliabilitas konstruk yaitu nilai Composite Reliability harus lebih besar dari 0,7 .

Berikut rumus untuk menghitung Composite Reliability:

$P C=\frac{\left(\sum \lambda_{\mathrm{i}}\right)^{2} \operatorname{var} F}{\left(\sum \lambda_{\mathrm{i}}\right)^{2} \operatorname{var} F+\sum \Theta_{i i}}$

Keterangan:

$\lambda_{\mathrm{i}}$ adalah factor loading, $F$ adalah factor variance, $\Theta_{\mathrm{ii}}$ adalah error variance.

d. Average Variance Extracted (AVE)

Cara lain untuk menguji validitas discriminant adalah dengan membandingkan akar kuadrat dari AVE untuk setiap konstruk dengan nilai korelasi antar konstruk dalam model. Validitas discriminant yang baik ditunjukan dari akar kuadrat AVE untuk tiap konstruk lebih besar dari korelasi antar konstruk dalam model. Nilai AVE direkomendasikan harus lebih besar dari 0,50 .

Berikut rumus untuk menghitung AVE:

$\mathrm{AVE}=\frac{\left(\sum \lambda i^{2}\right) \operatorname{var} F}{\left(\sum \lambda i^{2}\right) \operatorname{var} F+\sum \Theta_{i i}}$

Keterangan:

$\lambda_{\mathrm{i}}$ adalah factor loading, $F$ adalah factor variance, $\Theta_{\mathrm{ii}}$ adalah error variance.

Nilai AVE yang diharapkan $>0,5$.

e. Cronbach Alpha.

Uji reliabilitas diperkuat dengan cronbach Alpha dan nilai yang diharapkan adalah $>0,6$ untuk semua konstruk. 
2. Evaluasi Model Struktural (Inner Model)

Evaluasi Model Struktural dilakukan dengan melihat nilai $R$ - Square untuk setiap variabel endogen sebagai kekuatan prediksi dari model structural (inner model) Interpretasinya sama dengan interpretasi OLS pada regresi. $\mathrm{Q}^{2}$ predictive relevance untuk model struktural mengukur seberapa baik nilai observasi dihasilkan oleh model dan juga estimasi parameternya. Nilai Q2 >0 menunjukan bahwa model mempunyai predictive relevance, sedangkan nilai Q2 < 0 menunjukan bahwa kurang memiliki predictive relevance.

Perhitungan Q-Square dapat dilakukan dengan rumus:

$$
\mathrm{Q}^{2}=1-\left(1-\mathrm{R}_{1}^{2}\right)\left(1-\mathrm{R}_{2}^{2}\right) \ldots\left(1-\mathrm{R}_{\mathrm{p}}^{2}\right)
$$

dimana $R_{1}^{2}, R_{2}^{2}, R_{p}^{2}$ adalah $R$ - Square variabel endogen dalam model persamaan.

Besaran $Q^{2}$ memiliki rentang $0<Q^{2}<1$, dimana semakin mendekati 1 berarti model semakin baik.

\section{HASIL}

\subsection{Gambaran Umum Objek Penelitian}

BNN Provinsi Kalimantan Tengah berdiri pada tanggal 1 Oktober tahun 2011 berdasarkan Undang-Undang Nomor: 35 tahun 2009 tentang Narkotika. Pada awalnya kantor BNN Provinsi Kalimantan Tengah beralamat di Jalan A. Yani no 26 E Palangka Raya. Kemudian pada tahun 2012, Kantor BNN Provinsi Kalimantan Tengah beralih ke Jalan Cilik Riwut Km. 1 di depan Polda Kalimantan Tengah. Selanjutnya pada tahun 2014 mendapat hibah tanah dari Pemerintah Kota Palangka Raya di Jalan Tangkasiang, yang kemudian dibangun Gedung Kantor BNN Provinsi Kalimantan Tengah lantai 2 dengan alamat jalan Tangkasiang no 12 Kecamatan Jekan Raya.

Sejak tahun 2011-2015, BNN Provinsi Kalimantan Tengah dipimpin oleh Bapak Dwi Swasono, SE, MMA yang berasal dari Pegawai Negeri Sipil (PNS) Kemudian pada tahun 2015-2016 dipimpin oleh Bapak Kombes Pol A. Kadarmanta, S.Sos, MM, M.Si yang berasal dari Anggota Polri. Pada tahun 2016-2017 terjadi lagi pergantian pimpinan, yaitu Bapak Kombes Pol Drs. Sumirat Dwiyanti, M.Si. Pada tahun 2017 selama lebih kurang 3 bulan BNN Provinsi Kalimantan Tengah dipimpin oleh Brigjen Pol Drs. Triwarno Atmojo. Selanjutnya pada tahun 2017 sampai dengan sekarang BNN Provinsi Kalimantan Tengah dipimpin oleh Bapak Brigjen Pol Drs. Lilik Heri Setiadi, M.Si.

\subsection{Karakteristik Responden}

Responden dalam penelitian ini adalah seluruh pegawai BNNP Kalimantan Tengah, yaitu sebanyak 37 orang, yang terdiri dari Polri sebanyak 10 orang, pegawai negeri sipil (PNS) sebanyak 23 orang, dan tenaga kerja kontrak (TKK) sebanyak 4 orang. Berdasarkan data yang berhasil dikumpulkan dalam penelitian ini, kuesioner yang dibagikan berjumlah 37 eksemplar kepada seluruh pegawai BNNP Kalimantan Tengah.

Karakteristik responden dalam penelitian ini diperinci menurut jenis kelamin, usia, dan tingkat pendidikan, dalam BNNP Kalimantan Tengah yang digambarkan pada Tabel dibawah ini.

Tabel 2. Karakteristik responden berdasarkan jenis kelamin

\begin{tabular}{ccc}
\hline Jenis Kelamin & Frekuensi & Persentase \\
\hline Laki-laki & 21 & $56,75 \%$ \\
Perempuan & 16 & $43,25 \%$ \\
\hline Total & $\mathbf{3 7}$ & $\mathbf{1 0 0 , 0 0 \%}$ \\
\hline
\end{tabular}

Tabel 2 menunjukkan bahwa responden dalam penelitian ini sebagian besar berjenis kelamin laki-laki sebanyak 21 orang (56,75\%) dan berjenis kelamin perempuan sebanyak 16 orang (43,25\%).

Tabel 3. Karakteristik responden berdasarkan usia

\begin{tabular}{ccc}
\hline Usia & Frekuensi & Persentase \\
\hline $26-30$ & 16 & $43,24 \%$ \\
$31-35$ & 7 & $18,91 \%$ \\
$36-40$ & 3 & $8,10 \%$ \\
$41-45$ & 5 & $13,51 \%$ \\
$46-50$ & 2 & $5,40 \%$ \\
$>51$ & 4 & $10,84 \%$ \\
\hline Total & $\mathbf{3 7}$ & $\mathbf{1 0 0 , 0 0 \%}$ \\
\hline
\end{tabular}

Tabel 3 menunjukkan bahwa responden dalam penelitian ini didominasi oleh responden yang berusia 26 -30 tahun yaitu sebanyak 16 orang $(43,24 \%)$, dilanjutkan dengan usia 31-35 tahun sebanyak 7 orang $(18,91 \%)$, usia 36-40 tahun sebanyak 3 orang (8,1\%), usia 41-45 sebanyak 5 orang (13,51\%), usia 46-50 sebanyak 2 orang $(5,4 \%)$ dan terakhir berusia $>51$ tahun sebanyak 4 orang (10,84\%).

Tabel 4. Karakteristik responden berdasarkan tingkat pendidikan

\begin{tabular}{ccc}
\hline Tingkat Pendidikan & Frekuensi & Persentase \\
\hline D3 & 7 & 18,91 \\
S1 & 25 & 67,56 \\
S2 & 5 & 13,53 \\
\hline Total & 37 & $100 \%$ \\
\hline
\end{tabular}

Tabel 4 menunjukkan bahwa responden dengan tingkat pendidikan S2 sebanyak 5 orang (13,53\%), S1 sebanyak 25 orang $(67,56 \%)$ dan sisanya yaitu tingkat pendidikan D3 sebanyak 7 orang (18,91\%). 


\subsection{Analisis Data}

Analisis deskriptif dilakukan untuk mendapatkan persepsi responden terhadap pertanyaan atau pernyataan yang diberikan tentang variabel-variabel penelitian yang digunakan. Metode yang digunakan adalah dengan distribusi frekuensi. Distribusi frekuensi adalah statistik yang digunakan untuk menggambarkan distribusi dari jawaban responden atas berbagai item variabel yang diteliti.

Pada Tabel 5 tampak bahwa jawaban responden memiliki variasi yang sangat lebar ditunjukkan dengan nilai minimal 2 (tidak setuju) dan maksimal 5 (sangat setuju) Variabel Kompetensi (X1) berisi 4 indikator dan direfleksikan dengan jawaban kuesioner yang berkode X1.1 sampai dengan X1.4. Hasil menunjukkan bahwa nilai rata-rata indikator dari Kompetensi (X1) memiliki nilai mean variabel sebesar 4,155. Hasil tersebut merupakan gambaran yang umumnya responden menjawab setuju dengan seluruh pernyataan pada kuesioner tersebut mengenai kompetensi.

Lebih lanjut Tabel 6 menyajikan hasil deskriptif variabel Insentif (X2) yang memiliki variasi tinggi dengan nilai minimal 2 (tidak setuju) dan nilai maksimal 5 (sangat setuju) Nilai rata-rata (mean variabel) semua indikator sebesar 3,778. Hasil ini menjelaskan bahwa 37 responden rata-rata cenderung setuju dengan pernyataan dalam kuesioner tersebut mengenai insentif.

Pada Tabel 7 tampak bahwa 37 responden memiliki variasi jawaban yang tinggi dengan nilai minimal 2 (tidak setuju) dan maksimal 5 (sangat setuju) Variabel Motivasi (X3) berisi 8 indikator dan direfleksikan dengan jawaban kuesioner yang berkode X3.1 sampai dengan X3.8. Hasil ini mengindikasikan bahwa nilai rata-rata responden sebesar 3,639. Dengan kata lain, temuan ini menggambarkan bahwa 37 responden rata-rata berpendapat cenderung setuju atas semua pertanyaan yang berkaitan dengan motivasi.

Tabel 5. Deskriptif statistik kompetensi (X1)

\begin{tabular}{|c|c|c|c|c|c|}
\hline No & Kuesioner & Kode & Mean & Min & Max \\
\hline 1 & $\begin{array}{l}\text { Dalam melaksanakan pekerjaan, pegawai memiliki ilmu pengetahuan } \\
\text { yang sesuai }\end{array}$ & $\mathrm{X} 1.1$ & 4,297 & 2 & 5 \\
\hline 2 & Pegawai memiliki keahlian dalam melaksanakan pekerjaan & $\mathrm{X} 1.2$ & 3,919 & 2 & 5 \\
\hline 3 & Pegawai memiliki karakter yang kuat dalam melaksanakan pekerjaan & $\mathrm{X} 1.3$ & 4,243 & 2 & 5 \\
\hline 4 & $\begin{array}{l}\text { Sikap dalam melakukan kerja sama sangat mendukung keberhasilan } \\
\text { dalam menjalankan tugas }\end{array}$ & $\mathrm{X} 1.4$ & 4,162 & 3 & 5 \\
\hline \multicolumn{2}{|r|}{ Mean variabel } & $\mathbf{X} 1$ & 4,155 & 2 & 5 \\
\hline
\end{tabular}

Tabel 6. Deskriptif statistik insentif (X2)

\begin{tabular}{|c|c|c|c|c|c|}
\hline No & Kuesioner & Kode & Mean & Min & Max \\
\hline 1 & Insentif yang diterima dapat memotivasi untuk bekerja lebih baik & $\mathrm{X} 2.1$ & 4,108 & 2 & 5 \\
\hline 2 & Besaran insentif sudah sesuai dengan standar yang ditentukan & $\mathrm{X} 2.2$ & 3,838 & 2 & 5 \\
\hline 3 & Insentif yang diterima sesuai dengan harapan & $\mathrm{X} 2.3$ & 3,676 & 2 & 5 \\
\hline 4 & Insentif diberikan berdasarkan prestasi kerja & $\times 2.4$ & 3,703 & 2 & 5 \\
\hline 5 & Insentif diberikan sesuai dengan beban kerja yang dilaksanakan & $\mathrm{X} 2.5$ & 3,568 & 2 & 5 \\
\hline \multicolumn{2}{|r|}{ Mean variabel } & $\mathbf{X 2}$ & 3,778 & 2 & 5 \\
\hline
\end{tabular}

Tabel 7. Deskriptif statistik motivasi (X3)

\begin{tabular}{|c|c|c|c|c|c|}
\hline No & Kuesioner & Kode & Mean & Min & Max \\
\hline 1 & Besarnya gaji yang diperoleh sesuai dengan yang dikerjakan & X3.1 & 3,459 & 2 & 5 \\
\hline 2 & Anda merasa tertantang untuk menyelesaikan pekerjaan yang diberikan & X3.2 & 3,757 & 2 & 5 \\
\hline 3 & $\begin{array}{l}\text { Anda selalu berinisiatif menjalankan pekerjaan tanpa harus menunggu } \\
\text { perintah dari atasan }\end{array}$ & $\mathrm{X} 3.3$ & 3,270 & 1 & 5 \\
\hline 4 & Adanya perhatian terhadap fasilitas yang mendukung pekerjaan anda & X3.4 & 3,541 & 2 & 5 \\
\hline 5 & $\begin{array}{l}\text { Anda selalu dilibatkan dalam pertemuan atau rapat dalam pengambilan } \\
\text { keputusan }\end{array}$ & X3.5 & 3,757 & 2 & 5 \\
\hline 6 & $\begin{array}{l}\text { Adanya perlakuan yang sama oleh atasan terhadap semua anggota/ } \\
\text { aparat }\end{array}$ & X3.6 & 3,703 & 2 & 5 \\
\hline 7 & Anda merasa nyaman dengan kondisi lingkungan anda bekerja & X3.7 & 3,757 & 2 & 5 \\
\hline 8 & $\begin{array}{l}\text { Atasan memberikan pujian apabila menyelesaikan pekerjaan dengan } \\
\text { memuaskan }\end{array}$ & $\mathrm{X} 3.8$ & 3,865 & 1 & 5 \\
\hline \multicolumn{2}{|r|}{ Mean variabel } & $\mathbf{X 3}$ & 3,639 & 2 & 5 \\
\hline
\end{tabular}


Tabel 8. Deskriptif statistik kinerja (Y)

\begin{tabular}{|c|c|c|c|c|c|}
\hline No & Kuesioner & Kode & Mean & Min & Max \\
\hline 1 & Anda menjalankan target kerja yang telah ditetapkan instansi & Y1 & 3,135 & 1 & 5 \\
\hline 2 & Anda merasa senang dan puas dengan hasil kerja yang dicapai & Y2 & 3,568 & 2 & 5 \\
\hline 3 & Anda jarang melakukan kesalahan dalam melaksanakan tugas & Y3 & 3,784 & 2 & 5 \\
\hline 4 & $\begin{array}{l}\text { Anda selalu meneliti kembali setiap tugas yang diberikan sebelum } \\
\text { disampaikan ke atasan }\end{array}$ & Y4 & 3,405 & 2 & 5 \\
\hline 5 & Anda mampu menyelesaikan pekerjaan tanpa bantuan orang lain & Y5 & 3,189 & 1 & 5 \\
\hline 6 & $\begin{array}{l}\text { Anda mampu menyelesaikan pekerjaan yang diberikan atasan } \\
\text { dalam waktu yang telah ditentukan }\end{array}$ & Y6 & 3,000 & 1 & 5 \\
\hline 7 & $\begin{array}{l}\text { Pengetahuan akan pekerjaan dapat membantu anda dalam } \\
\text { mengatasi permasalahan yang muncul pada saat bekerja }\end{array}$ & Y7 & 4,108 & 2 & 5 \\
\hline 8 & $\begin{array}{l}\text { Anda bertanggungjawab terhadap pekerjaan yang diberikan } \\
\text { atasan }\end{array}$ & Y8 & 4,027 & 2 & 5 \\
\hline 9 & $\begin{array}{l}\text { Dengan pengetahuan yang dimiliki, anda lebih menguasai bidang } \\
\text { tugas yang anda kerjakan }\end{array}$ & Y9 & 3,811 & 2 & 5 \\
\hline 10 & Anda selalu hadir tepat waktu & Y10 & 3,027 & 2 & 5 \\
\hline 11 & Anda mentaati peraturan yang berlaku di instansi & Y11 & 3,784 & 2 & 5 \\
\hline 12 & $\begin{array}{l}\text { Anda mampu memberikan solusi terhadap permasalahan yang } \\
\text { dihadapi }\end{array}$ & Y12 & 3,649 & 2 & 5 \\
\hline 13 & Anda berpikir kreatif guna kepentingan pekerjaan yang diperlukan & Y13 & 4,081 & 2 & 5 \\
\hline \multicolumn{2}{|r|}{ Mean variable } & $\mathbf{Y}$ & 3,582 & 2 & 5 \\
\hline
\end{tabular}

Tabel 8 menyajikan hasil deskriptif variabel kinerja $(Y)$ yang memiliki variasi tinggi dengan nilai minimal 2 (tidak setuju) dan nilai maksimal 5 (sangat setuju). Nilai ratarata (mean) semua indikator sebesar 3,582. Hasil ini menjelaskan bahwa 37 responden rata-rata cenderung setuju dengan pernyataan dalam kuesioner tersebut mengenai kinerja.

\subsection{Pengujian Outer Model}

Pada tahap awal, estimasi model outer model dijalankan untuk menguji hubungan indikator dengan variabel latennya. Uji ini untuk memastikan kelayakan dari setiap indikator, yaitu indikator harus memiliki validitas dan reliabilitas yang baik. Evaluasi outer model pada penelitian dijalankan sebanyak 3 (tiga) kali dengan asumsi nilai loading factor harus lebih besar dari 0,6.

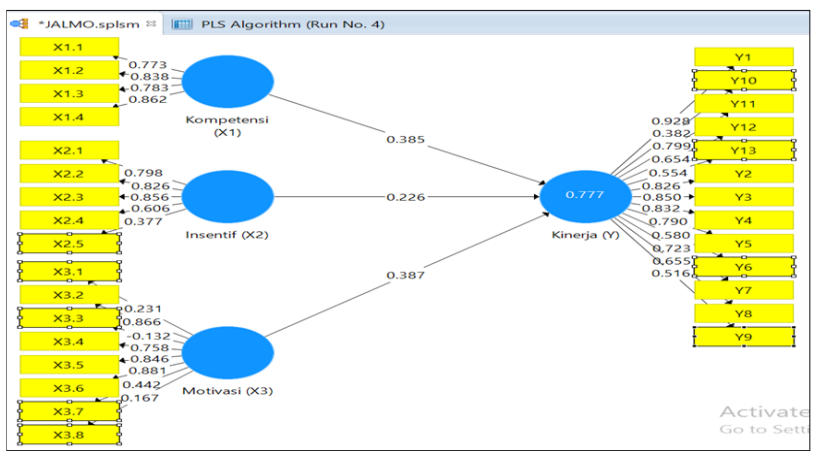

Gambar 1. Pengujian outer model tahap 1
Gambar 1 menunjukkan pengujian ke 1 bahwa terdapat indikator yang memiliki nilai loading factor pada kisaran < 0,6 dan harus dieliminasi. Indikator yang dieliminasi dan harus di drop adalah refleksi variabel insentif (X2) yaitu X2.5. Pada variabel motivasi (X3) indikator yang harus dieliminasi adalah X3.1; X3.3; X3.7; $X 3.8$. Selanjutnya pada variabel kinerja $(Y)$ indikator yang harus dieliminasi yaitu Y6, Y9, Y10 dan Y13. Dengan demikian, model harus dijalankan ulang atau diperlukan pengujian outer model ke 2 untuk memastikan bahwa semua indikator memiliki nilai $>0,6$.

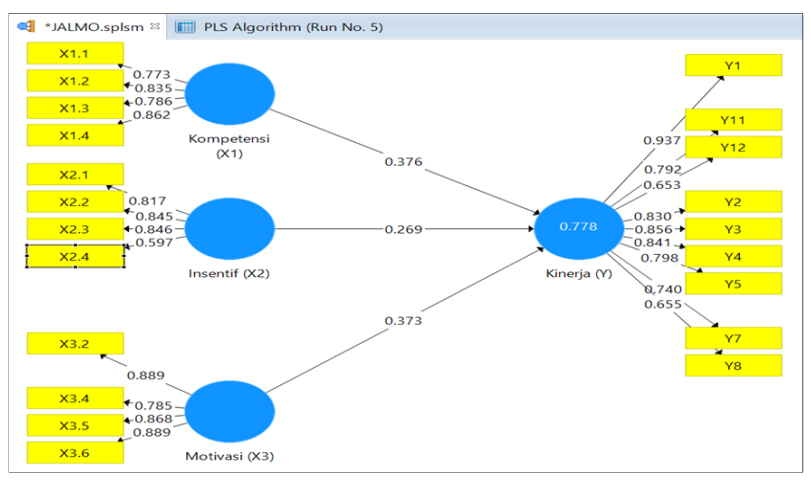

Gambar 2. Pengujian outer model tahap 2

Pada pengujian outer model tahap ke 2 (Gambar 2) tampak bahwa masih ada variabel dengan indikator memiliki nilai $>0,6$. Indikator yang dieliminasi dan harus di drop adalah refleksi variabel insentif (X2) yaitu X2.4. Dengan demikian, model harus dijalankan ulang atau 
diperlukan pengujian outer model ke 3 untuk memastikan bahwa semua indikator memiliki nilai $>0,6$.

Pengujian outer model tahap ke 3 (Gambar 3) menunjukkan bahwa semua variabel memiliki nilai loading factor pada kisaran $<0,6$. Variabel Kompetensi (X1) menyisakan 4 indikator yaitu X1.1; X1.2; X1.3 dan $X 1.4$. Variabel Insentif (X2) tersisa sebanyak 3 indikator yaitu X2.1, X2.2 dan X2.3. Variabel motivasi (X3) menyisakan 4 indikator yaitu X3.2; X3.4; X3.5 dan X3.6. Selanjutnya variabel kinerja $(Y)$ menyisakan 9 indikator yaitu Y1, Y2, Y3, Y4, Y5, Y7, Y8, Y11, dan Y12. Dengan demikian, dalam model penelitian ini tersisa 20 indikator yang layak dilakukan pengujian untuk tahapan selanjutnya.

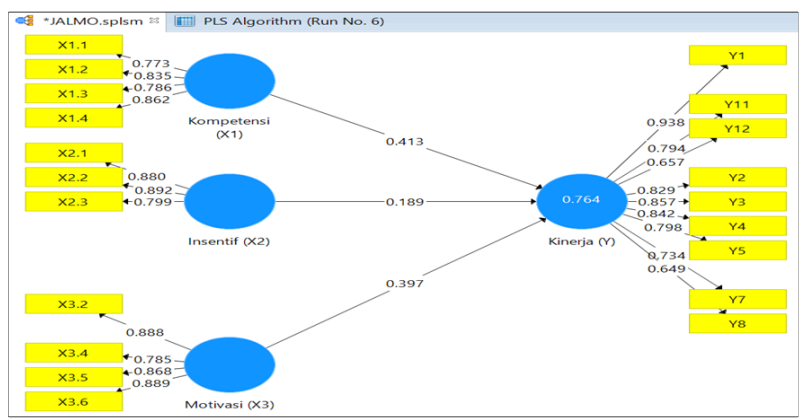

Gambar 3. Pengujian outer model tahap 3

\subsection{Uji Validitas}

Kuesioner yang merupakan refleksi dari pendapat responden didalam indikator yang dijadikan sebagai alat ukur dapat mengestimasi variabelnya masing-masing dengan baik dan secara tepat.

Tabel 9 adalah convergent validity yang menunjukkan bahwa semua indikator memiliki nilai outer loading $>0,6$. Tampak bahwa semua indikator disemua variabel memiliki nilai outer loading lebih besar dari 0,6 bahkan lebih besar dari 0,7. Bukti empiris ini menunjukkan bahwa semua indikator dalam model ini dapat dikatakan memiliki validitas yang baik.

\subsection{Uji Reliabilitas}

Pada penelitian ini nilai composite reliability lebih tinggi dari batas toleransi 0,6. Sementara itu, nilai AVE lebih tinggi dari batasan yang direkomendasikan yaitu > 0,5. Bukti hasil SEM-PLS terlihat pada Tabel 10.

Tabel 10. Uji reliabilitas

\begin{tabular}{lcc}
\hline \multicolumn{1}{c}{ Variabel } & $\begin{array}{c}\text { Composite } \\
\text { Reliability }\end{array}$ & $\begin{array}{c}\text { Average Variance } \\
\text { Extracted (AVE) }\end{array}$ \\
\hline Kompetensi (X1) & 0,887 & 0,664 \\
Insentif (X2) & 0,893 & 0,736 \\
Motivasi (X3) & 0,918 & 0,737 \\
Kinerja (Y) & 0,938 & 0,630 \\
\hline
\end{tabular}

Hasil ini menunjukkan bahwa semua konstruk atau variabel dalam penelitian ini memiliki reliabilitas yang baik.

Tabel 9. Outer loading

\begin{tabular}{ccccc}
\hline Matrix & Kompetensi & Insentif & Motivasi & Kinerja \\
\hline X1.1 & 0,773 & & & \\
X1.2 & 0,835 & & \\
X1.3 & 0,786 & & \\
X1.4 & 0,862 & 0,880 & \\
X2.1 & & 0,892 & \\
X2.2 & 0,799 & & \\
X2.3 & & 0,888 & \\
X3.2 & & 0,785 & \\
X3.4 & & 0,868 & \\
X3.5 & & 0,889 & \\
X3.6 & & & 0,938 \\
Y1 & & & 0,794 \\
Y11 & & 0,657 \\
Y12 & & 0,829 \\
Y2 & & & 0,857 \\
Y3 & & & 0,842 \\
Y4 & & 0,798 \\
Y5 & & & 0,734 \\
Y7 & & 0,649 \\
Y8 & & & \\
\hline
\end{tabular}




\subsection{Pengujian Inner Model}

Selanjutnya, inner model diuji menggunakan menggunakan SEM-PLS dengan menjalankan bootstrapping. Gambar 4 merupakan hasil uji inner model pada penelitian ini yang menggunakan fungsi moderasi dan semua variabel berbentuk reflektif. Sejalan dengan pendapat Chin (dalam Ghozali dan Latan, 2012) jika konstruk eksogen (variabel independen) berbentuk reflektif maka metode yang tepat untuk menguji moderasi yaitu dengan menggunakan product indicator approach.

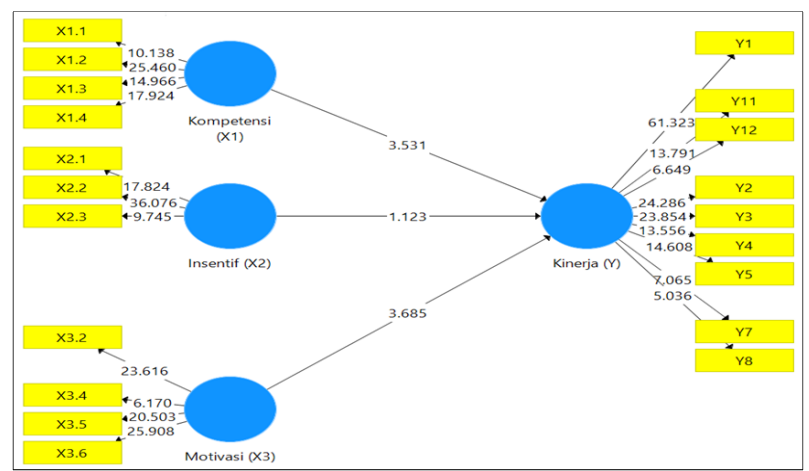

Gambar 4. Inner model

\subsection{Pengujian Goodness of Fit}

Pengujian ini digunakan untuk mengetahui kemampuan konstruk eksogen (variabel independen) dalam menjelaskan variasi pada konstruk endogen (variable dependen) Uji ini menggunakan nilai $R$-squared Adjusted karena variable independen pada model lebih dari satu variabel. Model pada penelitian ini menguji variabel kompetensi $\left(X_{1}\right)$, Insentif $\left(X_{2}\right)$ dan Motivasi $\left(X_{3}\right)$, sebagai variabel independen. Selanjutnya, variabel kinerja $(Y)$ sebagai variabel dependen.

Table 11. $R$-squared adjusted

\begin{tabular}{ccc}
\hline Model & R-square & $\begin{array}{c}\text { R-square } \\
\text { Adjusted }\end{array}$ \\
\hline Kinerja $(Y)$ & 0,764 & 0,742 \\
\hline
\end{tabular}

Tabel 11 menunjukkan nilai $R$-squared Adjusted untuk variabel Kinerja (Y) sebesar 0,724. Bukti empiris ini mengindikasikan bahwa perubahan kompetensi $\left(X_{1}\right)$, insentif $\left(X_{2}\right)$ dan motivasi $\left(X_{3}\right)$ dapat menjelaskan perubahan dari kinerja $(Y)$ sebesar $72,4 \%$. Sedangkan selebihnya, $27,6 \%$ dijelaskan oleh variabel lain diluar model penelitian ini.

\subsection{Pengujian Hipotesis}

Nilai signifikansi pada P-value dan T-statistik merupakan ukuran untuk melihat signifikansi pengaruh variabel independen terhadap variabel dependen. Berdasarkan tingkat kepercayaan 95\% maka taraf signifikansi 5\% dan $P$-value harus $<0,05$.

Tabel 12 menyajikan bukti empiris temuan pada hubungan antar variabel tersebut. Penjelasan dari setiap pengujian dapat dijabarkan sebagai berikut:

1. Pengujian hipotesis 1: Pengaruh kompetensi terhadap kinerja

Pada Tabel 5.10 poin 1 memberikan bukti bahwa nilai $P$-value adalah 0,000 $<0,05$ dan nilai T-statistik 3,511

$>$ 2,026. Hasil ini menerima hipotesis 1 bahwa Kompetensi berpengaruh signifikan terhadap Kinerja dengan taraf signifikansi 5\%. Temuan ini juga menggambarkan bahwa variasi dari Kompetensi dapat menjelaskan variasi dari knerja.

2. Pengujian hipotesis 2: Pengaruh insentif terhadap kinerja

Tabel 5.10 poin 2 memberikan bukti bahwa nilai $P$ value adalah 0,117>0,05 dan nilai T-statistik 1,189< 2,026. Hasil ini menolak hipotesis 2 bahwa Insentif berpengaruh signifikan terhadap Kinerja dengan taraf signifikansi 5\%. Temuan ini juga menggambarkan bahwa variasi dari Insentif tidak dapat menjelaskan variasi dari kinerja.

3. Pengujian hipotesis 3: Pengaruh motivasi terhadap kinerja

Berdasarkan Tabel 5.10 poin 3 tampak bahwa nilai $P$ value 0,000 0,05 dan nilai T-statistik 3,725 > 2,026. Hasil ini menerima hipotesis 3 bahwa Motivasi berpengaruh signifikan terhadap Kinerja dengan taraf signifikansi 5\%. Dengan kata lain, berbagai variasi Motivasi mampu menjelaskan perubahan dari Kinerja secara signifikan.

\section{PEMBAHASAN}

\subsection{Pengaruh Kompetensi Terhadap Kinerja}

Pengaruh kompetensi terhadap kinerja merupakan pengaruh positif. Terlihat kompetensi individu dengan nilai thitung > tTabel atau 3,511 > 2,026, maka kompetensi berpengaruh positif terhadap kinerja. Dengan kata lain ada pengaruh yang signifikan antara kompetensi terhadap kinerja pegawai di BNNP Kalimantan Tengah.

Tabel 12. Path coefficients

\begin{tabular}{clcccc}
\hline No & Pengaruh Langsung & Koefisien & t-statistik & P-value & Hipotesis \\
\hline 1 & Kompetensi $(\mathrm{X} 1) \rightarrow$ Kinerja $(\mathrm{Y})$ & 0,413 & 3,511 & 0,000 & H1 diterima \\
2 & Insentif $(\mathrm{X} 2) \rightarrow$ Kinerja $(\mathrm{Y})$ & 0,189 & 1,189 & 0,117 & $\mathrm{H} 2$ ditolak \\
3 & Motivasi $(\mathrm{X} 3) \rightarrow$ Kinerja $(\mathrm{Y})$ & 0,397 & 3,725 & 0,000 & $\mathrm{H} 3$ diterima \\
\hline
\end{tabular}


Berdasarkan temuan empiris, hal ini terjadi karena Kompetensi yang direfleksikan dengan pengetahuan, keahlian dan karakter mampu memberikan pengaruh nyata terhadap Kinerja yang didasarkan dengan menjalankan target kerja yang telah ditetapkan instansi, merasa puas dengan hasil kerja yang dicapai, jarang melakukan kesalahan dalam melaksanakan tugas, selalu meneliti kembali setiap tugas yang diberikan sebelum disampaikan ke atasan, mampu menyelesaikan pekerjaan tanpa bantuan orang lain, Pengetahuan membantu dalam mengatasi permasalahan yang muncul pada saat bekerja, bertanggungjawab terhadap pekerjaan, mentaati peraturan yang berlaku serta mampu memberikan solusi terhadap permasalahan yang dihadapi. Dalam hal ini kompetensi mempunyai peranan yang amat penting, karena tanpa adanya kompetensi maka seseorang akan sulit menyelesaikan pekerjaan tersebut sesuai dengan standar yang dipersyaratkan.

Hadiwijaya dan Hanafi (2016) mengemukakan pentingnya pengetahuan dalam peningkatan sumberdaya manusia sangat diperlukan. Mengingat pengetahuan memberikan andil didalam melakukan pemberdayaan organisasi atau pemberdayaan masyarakat. Pengetahuan tidak terlepas dari 3 unsur yaitu; jenjang pendidikan yang diamati, latar belakang pendidikan yang dimiliki dan disiplin ilmu yang ditekuni. Kemampuan fisik memiliki makna penting khusus untuk melakukan pekerjaan yang kurang menuntut keterampilan. Kompetensi yang diperlukan seseorang dapat diukur berdasarkan 5 sifat/karakteristik dapat dilihat dari pikiran, sikap, dan perilaku.

Temuan ini sejalan dengan penelitian Marpaung et al. (2015) yang menyatakan bahwa kompetensi berpengaruh terhadap kinerja Pegawai Perum Bulogdivre Kampar. Selanjutnya hasil penelitian ini sejalan dengan Bahtiar (2016) yang menyatakan bahwa kompetensi berpengaruh terhadap kinerja Karyawan pada Koperasi Mandiri Sejahtera Maesan Bondowoso.

\subsection{Pengaruh Insentif Terhadap Kinerja}

Berdasarkan hasil uji $t$ diketahui bahwa variabel insentif dengan nilai $t_{\text {hitung }}>\mathrm{t}_{\text {Tabel }}$ atau 1,189 2,026 dengan demikian insentif tidak berpengaruh positif terhadap kinerja. Dengan kata lain tidak ada pengaruh yang signifikan Insentif terhadap kinerja pegawai di BNNP Kalimantan Tengah. Insentif yang digambarkan melalui: (1) insentif yang diterima dapat memotivasi untuk bekerja lebih baik, (2) besaran insentif sudah sesuai dengan standar yang ditentukan, dan (3) insentif yang diterima sesuai dengan harapan tidak dapat memberikan perubahan pada kinerja. Fakta yang ada insentif menjadi sesuatu yang berwujud namun dirasakan semu oleh pegawai karena dianggap hanya sebagai hak mutlak, bukan sebagai kompensasi atas pekerjaan.

Pengaruh insentif terhadap kinerja karyawan yang tidak signifikan menandakan bahwa pegawai BNNP Kalimantan Tengah hanya sedikit menggunakan insentif sebagai pengukur kinerja pegawai. Insentif yang diberikan kepada pegawai kurang merata misalnya bagian administrasi yang dalam bekerja tidak dituntut untuk mencapai target yang diharuskan sehingga insentif tidak berpengaruh terhadap kinerja pegawai.

Pegawai BNNP Kalimantan Tengah dapat menerima insentif apabila kinerja mereka melebihi dari hasil kerjanya. Insentif tersebut tidak hanya berwujud bonus uang tunai, tetapi dapat berupa penghargaan atau pujian. Maka dari itu, pegawai BNNP Kalimantan Tengah merasa tidak mendapatkan hasil dari pemberian insentifnya. Pemberian insentif dari pegawai satu dengan yang lain berbeda-beda, tergantung kinerjanya juga. Perbedaan pemberian insentif tersebut disebabkan salah satunya, jenis atau golongan Pegawai Negeri Sipil yang berbeda-beda. Jenis atau golongan tersebut menentukan besar dan kecilnya insentif yang diberikan kepada masing-masing pegawai. Namun, karena adanya perbedaan jenis atau golongan tersebut berbeda-beda dan telah diketahui oleh masing-masing pegawai tersebut. Sehingga, pekerjaan yang dilakukan diluar pekerjaan pokok akan menghasilkan insentif yang berbeda-beda namun pekerjaan masing-masing pegawai tetap dilaksanakan.

Dengan kata lain, jika atasan mengapresiasi prestasi kerja pegawai dengan insentif yang tepat maka pegawai terdorong lebih kuat untuk mencapai target kerja yang ditetapkan, sebaliknya jika atasan kurang mengapresiasi prestasi kerja pegawai dengan insentif yang tepat maka pegawai untuk mencapai target kerja yang ditetapkan semakin menurun. Tujuan utama pemberian insentif adalah untuk memberikan tanggung jawab dan dorongan kepada pekerja guna meningkatkan kualitas, kuantitas da produktivitas hasil kerja.

Hasil penelitian ini sejalan dengan penelitian Akmal et al. (2018), yang menyatakan bahwa Insentif tidak berpengaruh terhadap kinerja karyawan PT. Media Fajar Koran Makasar. Penelitian ini bertujuan untuk mengetahui pengaruh insentif dan motivasi terhadap kinerja karyawan pada PT. Media Fajar Koran. Populasi dalam penelitian ini adalah karyawan PT. Media Fajar Koran yang berjumlah 100 orang.

\subsection{Pengaruh Motivasi Terhadap Kinerja}

Pengaruh motivasi terhadap kinerja merupakan pengaruh positif. Terlihat motivasi dengan nilai $t_{\text {hitung }}>$ tTabel atau 3,725 > 2,026, maka motivasi berpengaruh positif terhadap kinerja. Dengan kata lain ada pengaruh yang signifikan antara motivasi terhadap kinerja pegawai di BNNP Kalimantan Tengah. Adanya pekerjaan yang menantang, fasilitas, keterlibatan pegawai dan perlakuan yang sama dapat memicu pegawai merasa senang dan puas serta target kerja tercapai. Dengan kata lain semakin meningkatnya motivasi pegawai dapat mendorong peningkatan kinerja yang telah ditetapkan. Untuk meningkatkan kinerja pegawai Pemimpin memberi motivasi kepada pegawai di BNNP Kalimantan Tengah. 
Setiap pegawai dalam menjalankan tugas harus memiliki motivasi, karena motivasi merupakan salah satu unsur dalam perilaku individu yang menyangkut kebutuhan dan keinginan dari setiap pegawai yang berbeda satu sama lainnya. Hal ini secara langsung akan membawa dampak terhadap kinerja pegawai BNNP Kalimantan Tengah sehingga akan menghasilkan mutu layanan yang baik, artinya pegawai yang memiliki motivasi kerja yang baik maka kinerjanya akan lebih optimal.

Penelitian ini sejalan dengan penelitian yang dilakukan oleh Marcelia (2018) menyatakan bahwa motivasi berpengaruh terhadap kinerja pegawai Pada Dinas Pengelolaan Keuangan dan Aset Daerah (DPKAD) Kota Bandung. Selain itu hasil penelitian ini sejalan dengan Bahtiar (2016) yang menyatakan bahwa motivasi berpengaruh terhadap kinerja Perusahaan.

\section{KESIMPULAN}

Berdasarkan bukti empiris yang telah disajikan dan dianalisis, maka dapat disimpulkan bahwa kompetensi (X1) berpengaruh terhadap kinerja (Y) dengan taraf signifikansi 5\%. Dengan demikian, perubahan pada kompetensi (X1) dapat mempengaruhi perubahan terhadap kinerja $(Y)$.

Insentif $(X 2)$ tidak memiliki pengaruh yang signifikan terhadap kinerja ( $Y$ ) dengan taraf signifikansi 5\% (hipotesis 2 ditolak). Artinya bahwa perubahan dari insentif (X2) tidak mampu menjelaskan perubahan kinerja (Y) secara signifikan.

Motivasi (X3) memiliki pengaruh yang signifikan terhadap kinerja $(\mathrm{Y})$ melalui Motivasi $(\mathrm{X} 3)$ dengan taraf signifikansi 5\% (hipotesis 3 diterima). Dengan kata lain, perubahan dari motivasi (X3) mampu menjelaskan perubahan kinerja $(Y)$ secara signifikan.

Dari hasil penelitian ini, peneliti memberikan rekomendasi kepada pihak organisasi, yaitu hendaknya mengevaluasi dan menata ulang sistem peningkatan kompetensi dan motivasi pegawai, agar para pegawai dapat memaksimalkan kemampuan untuk pekerjaannya dengan posisi yang sesuai dengan keahliannya sehingga dapat meningkatkan kinerja semaksimal mungkin, dan memberikan informasi sistem insentif dengan mensosialisasikan kejelasan insentif yang akan diterima agar pegawai memiliki keinginan yang kuat dalam bekerja seta dapat menanamkan nilai-nilai organisasi yang mengarah kepada kejelasan akan kinerja.

Hasil ini juga membuktikan bahwa insentif tidak berpengaruh terhadap kinerja. Hal ini mengindikasikan bahwa hubungan tersebut tidaklah sederhana dan menjadi peluang research selanjutnya. Peneliti selanjutnya dapat melibatkan variabel mediasi antara insentif dan kinerja seperti motivasi, budaya kerja, organizational citizenship behavior dan kepuasan kerja.

\section{DAFTAR PUSTAKA}

Aisha, A. N., \& Hardjomidjojo, P., 2014. Evaluasi Sistem Insentif untuk Meningkatkan Performansi Kerja (Studi Kasus: Pegawai Non Akademik). Jurnal Ilmiah Teknik Industri, 13(1), 83-95.

Akmal, A., Asdi, A., \& Marhumi, S., 2018. Analisis Kompensasi Finansial Tidak Langsung Terhadap Motivasi Kerja Karyawan di PT. Prima Karya Manunggal Kabupaten Pangkep. Profitability: Jurnal Ilmu Manajemen, 2(1), 1-8.

Anoraga, P., 2019. Psikologi Kerja. Jakarta: Badan Litbangkes-Kementerian Kesehatan RI.

Armstrong, M., 2009. Seri Pedoman Manajemen, Manajemen Sumber Daya Manusia, Jakarta: Gramedia.

Bahtiar, P. S., 2016. Pengaruh Motivasi Kerja, Insentif dan Kompetensi terhadap Semangat Kerja Karyawan (Studi pada Karyawan Koperasi Mandiri Sejahtera Maesan Bondowoso). Disertasi. Jember: Universitas Muhammadiyah Jember.

Costa, A. C., Roe, R. A., \& Taillieu, T., 2001. Trust within teams: The relation with performance effectiveness. European journal of work and organizational psychology, 10(3), 225-244.

Dessler, G., 2009. Manajemen Sumber Daya Manusia. Jakarta: Salemba Empat.

Fahrul, B. S., 2016. Pengaruh Pemberian Insentife dan Kompetensi Karyawan Terhadap Kinerja Karyawan PG. Madukismo Yogyakarta. Badan Penerbit Universitas Negeri Yogyakarta.

Ghozali, I., 2012. Aplikasi Analisis Multivariate dengan Program IBM SPSS. Semarang: Universitas Diponegoro

Ghozali, I. \& Latan, H., 2012. Partial Least Square: Konsep, Teknik dan Aplikasi SmartPLS 2.0 M3. Semarang: Badan Penerbit Universitas Diponegoro.

Hadiwijaya, H. and Hanafi, A., 2016. Pengaruh Kompetensi dan Disiplin Terhadap Kepuasan Serta Implikasinya Pada Prestasi Kerja Karyawan. Jurnal Manajemen dan Bisnis Sriwijaya, 14(3), 407-418.

Handoko, T. H., 2013. Manajemen Personalia dan Sumber Daya Manusia. Yogyakarta: BPFE-UGM.

Hasibuan, M. S. P., 2005. Manajemen Sumber Daya Manusia. Edisi Revisi. Jakarta: Bumi Aksara.

Marcelia, M., 2018. Faktor-Faktor Yang Mempengaruhi Penetapan Margin Pembiayaan Murabahah Pada Bank Umum Syariah di Indonesia. Disertasi. Bandung: Universitas Pendidikan Indonesia.

Marpaung, R., Marnis, M., \& Setiawan, N., 2015. Pengaruh Kompetensi Individu, Insentif, dan Motivasi Intrinsik terhadap Kinerja Pegawai Perum Bulog Divre Kampar. Disertasi. Riau: Universitas Riau.

Moeheriono, 2010. Pengukuran Kinerja Berbasis Kompetensi. Bogor: Penerbit Ghalia Indonesia.

Robbins, S. L., 2002. Pocket companion to Robbins pathologic basis of disease. Elsevier Health Sciences TW. 
Ruky, A. S., 2006. Sistem Manajemen Kinerja. Jakarta: PT. Gramedia Pustaka Utama.

Sari, D. A. R., 2018. Pengaruh Kompetensi Terhadap Kinerja Guru dengan Kepuasan Kerja sebagai Varabel Mediasi. Skripsi. Bandar Lampung: Universitas Lampung.

Sari, H. P. (2019). Pengaruh Kompetensi, Motivasi Kerja dan Insentif Terhadap Kinerja Guru SMA. Perspektif Ilmu Pendidikan, 33(1), 69-78.

Solimun, A.M.P.S., 2010. Metode Partial Least SquarePLS. CV Citra Malang, Malang.
Sugiyono, 2012. Metode Penelitian Kuantitatif Kualitatif dan $R \& D$. Bandung: Alfabeta

Undang-Undang Republik Indonesia Nomor 35 Tahun 2009 Tentang Narkotika. (12 Oktober 2009) Lembaran Negara Republik Indonesia Tahun 2009 Nomor 143. Jakarta.

Wursanto, D., 2003. Dasar-Dasar Ilmu Organisasi. Yogyakarta: Andi. 